условия эффективного сочетания очного обучения и применения технологий дистанционного образования : автореф. дис. ... докт. пед. наук на соискание ученой степени: 13.00 .02 «Теория и методика обучения и воспитания (информатизация образования)» / Капустин Юрий Иванович; [Институт содержания и методов обучения РАО]. - М., 2007. - 68 с. 3. Рашевська Н. В. Мобільні інформаційно-комунікаційні технології навчання вищої математики студентів вищих технічних навчальних закладів: автореф. дис. на здобуття наук. ступеня канд. пед. наук: 13.00 .10 «Інформаційно-комунікаційні технології в освіті» / Рашевська Наталя Василівна; Інститут інформаційних технологій і засобів навчання НАПН України. - К., 2011. - 21 с. 4. Семеріков С. О. Теоретико-методичні основи фундаменталізації навчання інформатичних дисциплін у вищих навчальних закладах : дис. ... докт. пед. наук : 13.00.02 «Теорія та методика навчання (інформатика)» / Семеріков Сергій Олексійович; Національний педагогічний ун-т ім. М. П. Драгоманова. - К., 2009. 536 с. 5. Триус Ю. В. Комп'ютерно-орієнтовані методичні системи навчання математичних дисциплін у вищих навчальних закладах : дис. ... докт. пед. наук : 13.00 .02 «Теорія і методика навчання інформатики» / Триус Юрій Васильович; Черкаський національний ун-т ім. Богдана Хмельницького. - Черкаси, 2005. - 649 с.

олена Семеног

\title{
ФОРМУВАННЯ КОМУНІКАТИВНОӤ КОМПЕТЕНТНОСТІ МАЙБУТНІХ ЕКОНОМІСТІВ: АКСІОЛОГІЧНИЙ ПІДХІД
}

Семеног О. М. Формування комунікативної компетентності майбутніх економістів: аксіологічний підхід.

У статті з урахуванням сучасних підходів, зокрема аксіологічного підходу, охарактеризовано комунікативну компетентність економіста. За результатами дослідної роботи розроблено карти оцінювання сформованості комунікативної компетентності, апробовано методи (метод «мозкової атаки», рольові ділові ігри), які сприяють якісному формуванню комунікативної компетентності майбутніх економістів у вищому навчальному економічному закладі.

Ключові слова: комунікативна компетентність, майбутній економіст, аксіологічний підхід, ділова гра.

Семеног Е. Н. Формирование коммуникативной компетентности будущих экономистов: аксиологический подход.

В статье на основании современных подходов, в частности аксиологического подхода охарактеризовано коммуникативную компетентность экономиста. По результатам исследовательской работы разработаны карты оценивания сформированности коммуникативной компетентности, апробированы методы (метод «мозговой атаки», ролевые деловые игры) качественного формирования коммуникативной компетентности будущих экономистов в высшем учебном экономическом заведении.

Ключевые слова: коммуникативная компетентность, будущий экономист, аксиологический поход, деловая игра.

Semenog O. M. Communicative competence formation of future economists: axiological approach.

On the bases of modern approaches, including axiological approach in the article is described communicative competence of the economist. As a result of research are designed evaluation cards of communicative competence formation. Also are tested methods (methods of «brainstorming», business role games) that promotes qualitative communicative competence formation of future economists in high educational economic institution.

Key words: communicative competence, future economist axiological approach, business game.

Розбудова вітчизняної економіки актуалізує потребу в економістах, здатних успішно працювати на національних і міжнародних фінансових ринках. Такі фахівці повинні володіти грунтовними знаннями у фінансово-господарській, банківській, торговельно-економічній галузі, бути психологічно готовим здійснювати професійну діяльність, мобільно реагуючи на зміни у виробництві, вміти прогнозувати економічні процеси у галузі грошових, фінансових і кредитних відносин, прагнути до неперервного професійного розвитку, саморозвитку і самореалізації, тобто бути професійно компетентним. 
Вагоме місце у структурі професійної компетентності економістів займає комунікативна компетентність. Це означає практичне й усвідомлене володіння вміннями здійснювати усне i писемне, вербальне й невербальне професійно-ділове спілкування з урахуванням норм сучасної української літературної мови, здійснювати взаємообмін набутим досвідом, досягати взаєморозуміння між партнерами. Комунікативна компетентність постає одним з основних чинників позитивного іміджу фахівця, сприяє його успішній самопрезентації, ефективності розв'язання професійних завдань i, відповідно, значною мірою впливає на головний економічний показник розвитку підприємства - прибуток.

Однак, як показує аналіз, формуванню комунікативної компетентності майбутніх економістів у вищих економічних навчальних закладах увага приділяється недостатньою мірою, хоча $є$ в цьому потреби і регламентовано це галузевими стандартами вищої освіти. Вважається, що оволодіння професійною комунікацією і мовою фаху відбувається автоматично, під час опанування навчальних дисциплін. Невміння моделювати i самопроектувати професійну комунікацію загалом негативно впливає на якісні зміни в економіці держави. 3 огляду на це комунікативна підготовка економістів у вищих економічних навчальних закладах набуває особливої актуальності.

Аналіз наукових джерел засвідчує, що феномен комунікативної компетентності розглядається крізь призму спілкування як процес, що породжує спільність людей (М. Каган); спілкування як діалог (М. Бубер, М. Бахтін, Г. Батищев, М. Хайдегер, К. Ясперс). Комунікативну компетентність майбутніх фахівців, у тому числі економічного профілю досліджують у таких аспектах: як особистісну якість і поведінку, що виявляються у взаєминах (Б. Ананьєв, Г. Андреєва, М. Качан, О. Леонтьєв, А. Реан, В. Шепель та ін.); необхідний складник комунікативної культури (Н. Кузьміна, А. Маркова, С. Ромашина та ін.); здібність особистості (В. Гаркуша, Л. Петровська, К. Платонов та ін.); здатність швидко орієнтуватися в ситуації спілкування, що спирається на комунікативний досвід індивіда (Ю. Ємельянов, С. Бахтєєва та ін.); уміння вступати в комунікацію (М. Коломоєць, Н. Кузьміна, В. Пилипівська та ін.); інтегральну якість особистості, що синтезує загальну культуру спілкування та іiі виявлення у професійній діяльності (С. Ромашина, І. Ромащенко, В. Черевко та ін.). У контексті нашого дослідження важливими $є$ також роботи, присвячені питанням мовної культури у професійній сфері (Н. Бабич, 3. Бакум, І. Дороз, Р. Зорівчак, Л. Мацько, О. Сербенська, Л. Струганець), з'ясуванню особливостей професійної підготовки спеціалістів фінансовоекономічного профілю (Г. Ковальчук, М. Левочко, А. Нісімчук, Т. Поясок та ін.).

Набута комунікативна компетентність економіста - це також реалізація певної (визначеної) сукупності комунікативних знань, умінь, навичок, норм, ціннісних орієнтирів у професійній діяльності особистості, іiі творчого потенціалу, це здатність фахівця ціннісно й осмислено досягати спільності позицій з колегами і клієнтами з фінансово-економічних питань на основі вироблення стратегій взаємодії, прийняття і розуміння іншої людини. Разом з тим питання формування комунікативної компетентності особистості з урахуванням сучасних підходів, зокрема аксіологічного підходу, не набуло достатнього відображення в наукових джерелах.

У межах статті окреслимо професійну комунікативну підготовку економістів у вищих економічних навчальних закладах з урахуванням сучасних підходів, схарактеризуємо методи формування професійної комунікативної компетентності майбутніх економістів з урахуванням аксіологічного підходу.

Зазначимо, що поняття «підхід» означає вихідну позицію, що складає основу дослідницької діяльності. Загальною ідеєю компетентнісного підходу є компетентнісно-орієнтована освіта, що спрямована на комплексне засвоєння знань та способів практичної діяльності, завдяки яким людина успішно реалізує себе в різних галузях життєдіяльності [2, с. 60]. Специфіка компетентнісного підходу до професійної комунікативної підготовки майбутніх економістів полягає в тому, що засвоюються не «готові знання», а «прослідковуються умови походження цього знання». Критерієм якості такої підготовки постає професійна компетентність випускників вищих навчальних закладів як інтегральна особистісна якість, сукупність професійних компетенцій, що зумовлюють готовність до професійної діяльності.

Формування комунікативної компетентності майбутніх економістів передбачає звернення до діяльнісного підходу. Основна ідея підходу, що обгрунтований у працях Л. Виготського, О. Леонтьєва, С. Рубінштейна, а потім розвинутий П. Гальперіним, Д. Ельконіним, 
Л. Фрідманом та ін. полягає у твердженні: знання виробляються суб'єктом власної діяльності, засвоєння знань відбувається в поєднанні зі способами дій.

Важливий у процесі формування комунікативної компетентності майбутніх економістів культурологічний підхід. Таке навчання сприяє створенню оптимальних умов засвоєння загальнолюдської і національної культури, усвідомленню і самореалізації особистістю своїх культурних потреб, інтересів і здібностей. За культурологічного підходу визначальну роль відіграє широта загальногуманітарного світогляду студентів, їхня індивідуальність, здатність до творчої діяльності.

Культурологічний підхід як конкретно-наукова методологія пізнання й перетворення грунтується на аксіології (від грецького - цінність), ученні про цінності та ціннісну структуру світу. Реалізація аксіологічного підходу у професійній освіті (Б. Ананьєв, І. Блауберг, Б. Яворський) забезпечує гуманістичну орієнтацію освіти, розгляд особистості як найвищої цінності суспільства. Вона, дійсно, є найвищою цінністю, наголошує В. Рибалка, є джерелом і творцем інших, периферійних щодо неї духовних і матеріальних цінностей, а через їх продукування - і суб'єктом творення самої себе як центральної цінності» [3, с. 11].

Л. Хомич визначає категорію цінності особистості шляхом окреслення провідних цінностей у змісті навчання і виховання майбутніх фахівців: «Пріоритетними мають бути цінності життєспрямованості й мотивації життєдіяльності, цінності сфери усвідомлення змісту, мети процесу діяльності, цінності реалізації процесу діяльності, цінності, репрезентовані індивідуальними якостями суб'єкта діяльності» [4, с. 19]. У контексті дослідження йдеться про такі цінності, як: прагнення до свободи, життя, любові, дбайливості, кмітливості, колективізму, гідності, рівноваги, волелюбності, впевненості в собі. Цінності, виконуючи функцію стимулів, створюють умови для реалізації особистості. Система цінностей і ціннісних орієнтацій, які емоційно «забарвлюються» у процесі діяльності та визначають ставлення особистості до себе, інших людей і навколишнього світу, є одним із складників культури особистості.

Узагальнення позицій щодо сутності поняття комунікативної компетентності й наукових підходів до цієї інтегративної динамічної якості дає змогу окреслити компоненти комунікативної компетентності майбутнього економіста: комунікативно-ціннісний (характеризує мотивацію щодо встановлення контакту зі співрозмовником); особистісно-комунікативний (поєднує комунікативні риси, комунікативні здібності, комунікативні уміння); поведінково-дієвий (сприяє формуванню й розвитку творчих здібностей); комунікативно-когнітивний (визначає мовленнєву базу знань, що сприяє формуванню комунікативних умінь). Мовнокомунікативна особистість економіста - це так звана саморегулююча система, що знаходиться під впливом різноманітних соціальних і ситуативних факторів, соціального статусу, позиції «продавець - покупець», «гроші товар», мовної моди у сфері економічного спілкування. Отже, робота в аспекті формування комунікативної компетентності на заняттях $з$ мовних курсів має бути побудована так, щоб спонукати студентів мислити, здійснювати живе спілкування.

За результатами опитування студентів, що проводилося в Українській академії банківської справи (м. Суми), було розроблено карти оцінювання сформованості комунікативної компетентності. Карта оцінювання сформованості комунікативно-ціннісного компонента комунікативної компетентності «Внутрішні ресурси $\rightarrow$ орієнтація в ситуації спілкування» охоплює уміння переконувати, відстоювати власну позицію; стійкість поглядів; адекватну інтерпретацію отриманої інформації; уміння відповідати ситуації спілкування відповідно до швидкості змін аспектів взаємодії у процесі комунікації. Узагальнений аналіз дозволяє констатувати достатній рівень сформованості комунікативної компетентності за складником стійкість поглядів; середній - за адекватністю інтерпретації отриманої інформації; низький - за виявленням умінь переконувати, відстоювати власну позицію, взаємодіяти у процесі комунікації.

За картою оцінювання особистісно-комунікативного компонента «Взаємодія 3 навколишніми $\rightarrow$ адекватна орієнтація» (рефлексія, ідентифікація, емпатія, адекватна самооцінка, стереотипізація) визначено достатній рівень сформованості в респондентів емпатії; середній - рефлексії, адекватної самооцінки; низький - ідентифікації, стереотипізації.

За результатами опитування поведінково-дієвого компонента комунікативної компетентності «Регуляція комунікативних дій $\rightarrow$ соціальне середовище» (урівноваженість, витримка, зацікавленість, спроможність до самоосвіти, самовимогливість, організованість, уважність) виявлено таку картину: студенти й викладачі визнають високий рівень 
організованості та врівноваженості, достатній рівень розвитку витримки, зацікавленості, уважності, середній рівень вияву спроможності до самоосвіти; низький - самовимогливості.

У процесі оброблення карт оцінювання сформованості комунікативно-когнітивного компонента комунікативної компетентності «Конструктивне спілкування $\rightarrow$ контакт» (уміння слухати, сприймати й відтворювати; навички роботи в групі; уміння володіти різними соціальними ролями; уміння застосувати отримані теоретичні знання у процесі спілкування; уміння знаходити спільну мову зі співрозмовником) установлено часткове володіння високим рівнем вираження складника уміння слухати, сприймати й відтворювати; поряд із цим - достатній рівень навичок роботи у групі; більшість респондентів визнають середній рівень сформованості уміння знаходити спільну мову зі співрозмовником; низький - умінь застосування отриманих теоретичних знань у процесі спілкування притаманний більшості опитаних.

Отримані результати засвідчили: 35 відсотків респондентів переконані в необхідності підвищення рівня сформованості комунікативної компетентності; 47 відсотків опитаних визнають низький рівень комунікативної компетентності. У цьому контексті важливим $є$ пошук доцільних форм і методів формування комунікативної компетентності майбутніх економістів.

3-поміж ефективних методів, як показує апробація занять з курсу української мови за професійним спрямуванням, - методи «мозкової атаки», «евристичних питань», «круглого столу». «Мозкова атака», або брейксторм - це метод розв'язування невідкладних завдань за обмежений час. Метод мозкової атаки доречний у різних формах діяльності: в роботі з малими групами, командами, великими групами («гра 3 глядачами»), в індивідуальній роботі. Кейсметод передбачає розгляд виробничих ситуацій на фірмі, у банку, складних конфліктних випадків, проблемних ситуацій, інцидентів у процесі ведення торгів.

Робота в малих групах, наприклад, під час вивчення теми «Фінансова політика підприємств» із використанням методів аналізу ситуацій (метод кейсів, інцидентів) дозволяє більш ефективно залучати студентів до проблемної бесіди «Ваші дії», «Ваша версія». При цьому важливими є емоційність і захопленість викладача, створення співпраці, такт педагога, виконання студентами завдань з урахуванням їх схильностей та уподобань.

У практиці викладання активно використовують так званий «чорний ящик» (різновид мозкової атаки). Головною ознакою $є$ несподіваність у завданні, яке потрібно виконати; в ролі, яку необхідно зіграти; в ситуації, у якій важливо швидко зорієнтуватися. Неодмінними умовами для застосування методу є теоретична підготовленість у питанні, яке розглядається, довіра до викладача, зацікавленість студентів у розв'язанні проблеми, а мета використання навчитися висловлюватися стосовно питань, які виникають у швидкозмінних i непередбачуваних обставинах. Для обговорення студентам, зокрема, було запропоновано проблемні ситуативні питання культурологічного й аксіологічного спрямування. Наприклад: «Підприємець - революціонер в економіці. Прибуток для нього - лише символ успіху. Головне - ступити на незвіданий шлях там, де закінчується звичний порядок» (Й. Шумпетер).

Метод Дельфі передбачає індивідуальне генерування ідей та їх публічний захист. Наприклад, пропонуємо чотирьом учасникам скласти і захистити «мовленнєвий статут» брокерської контори, відповідаючи на запитання викладача і студентів. Моделювання мовних ситуацій сприяє творчому засвоєнню навчального матеріалу, розвитку активності, комунікативних здібностей, аналітичному мисленню, закріпленню професійних умінь і навичок.

Аналіз практичних занять із мовних та економічних дисциплін показав, що більшістю наставників студентської молоді доволі епізодично використовується ділова гра, що моделює ситуації реального спілкування. Причинами називають часто «несерйозне» сприймання гри на заняттях, неволодіння методикою гри, відсутність завдань для організації ігор.

Активна участь студентів у ділових іграх (рефлексивні, дидактичні, імітаційні), де викладач $\epsilon$ інформатором, організатором, консультантом, дозволяє відтворити предметний і соціальний зміст професійної діяльності, виховує культуру стосунків між партнерами гри. Важливими комунікативними компонентами мовлення і викладача і студента у грі постає змістовність (глибоке осмислення теми, головної думки висловлювання), точність (вибір слів, які найбільше відповідають висловлюваному змісту), логічність (тобто послідовність висловлювання відповідно до законів логіки), правильність (дотримання мовних норм), стислість викладу думок, доказовість, коректність та доречність вживання термінів, чистота мови, виразність, спрямованість на особистість. Багатство мовлення, зокрема, зумовлюється наявним лексичним 
запасом, залежить від загального активного запасу мовних засобів (слів, значень, моделей словосполучень і речень, типових інтонацій, зв'язків і відношень у тексті), сукупності навичок для цілеспрямованого застосування засобів мови.

Водночас разом із уведенням активних форм має змінитися і ставлення до навчання, що залишається в цілому традиційним. Дійсно, є слушним зауваження науковців: на зміну існуючому уявленню про те, що тренінгові форми допомагають у легкій, розважальній формі опановувати навчальний матеріал, має прийти розуміння, що ділові ігри, тренінги вимагають напруженої інтелектуальної праці кожної хвилини навчального часу. Використання на заняттях рольових ділових ігор сприяє якісній зміні ставлення до майбутньої професійної діяльності, як показує проведена дослідна робота: зростає прагнення встановлювати продуктивні відносини 3 колегами, можливості професійного розвитку, прагнення внести елемент творчості у професійну діяльність. 3'являється потреба більш глибокого і точного сприйняття усного слова, вміння виокремлювати 3 почутого раціональне зерно, коректно і стисло ставити питання, точно і стисло відповідати на питання партнерів, «шліфується» вміння слухати і чути. Застосування відеозйомки дає змогу побачити допущені помилки в мовленні, оцінити манеру здійснення дискусії, зовнішній вигляд, жестикуляцію - все, що може «зробити» комунікацію переконливішою або навпаки не донести до аудиторії важливої інформації.

Отже, формування комунікативної компетентності майбутніх економістів - це складний динамічний процес, що потребує цілісної системи роботи з урахуванням усіх структурних компонентів досліджуваного процесу в поєднанні аспектів розуміння різноманітних навчальних і життєвих ситуацій, умінь практичного використання набутих знань та, відповідно, усвідомлення необхідності самовдосконалення наявного особистісного рівня сформованості комунікативної компетентності. У наступних публікаціях зупинимося на більш детальному аналізі організаційно-педагогічних умов формування комунікативної компетентності майбутніх економістів.

\section{Література}

1. Бакум 3. П. Формування комунікативної компетентності майбутніх економістів: теоретикопрактичний аспект проблеми / З. П. Бакум, С. М. Хоцкіна // Педагогічні науки: зб. наук. пр. Вип. LVIII - Ч. 2. - Херсон : ХДУ, 2011. - С. 278-282. 2. Педагогический энциклопедический словарь/ гл. ред. Б. М. Бим-Бад. - М. : Большая Российская энциклопедия, 2003. - 527 с.: ил. 3. Рибалка В. В. Аксіологічні основи психологічної культури особистості: [навч.-метод. посіб.] / В. В. Рибалка. - Чернівці : Технодрук, 2009. - 228 с. 4. Хомич Л. О. Аксіологічні основи професійної підготовки майбутнього вчителя / Л. О. Хомич // Аксіологічний підхід - основа формування цілісності особистості майбутнього педагога: [монографія]; [за заг. ред. Л. О. Хомич]. - Київ-Ніжин : Видавець ПП Лисенко М. М., 2010. - С. 6-22.

УДК 177.9:340.11

Світлана Соколова

\section{КРИТЕРІЇ, ПОКАЗНИКИ ТА РІВНІ СФОРМОВАНОСТІ ПРАВОВОЇ КУЛЬТУРИ МАЙБУТНІХ ІНЖЕНЕРІВ-ПЕДАГОГІВ}

Соколова С. В. Критерії, показники та рівні сформованості правової культури майбутніх інженерів-педагогів.

У статті розглядаються мотиваційно-ціннісний, когнітивно-інформаційний, діяльнісноповедінковий, морально-особистісний та оцінно-рефлексивний критерії, показники і рівні сформованості правової культури майбутніх інженерів-педагогів. Визначено, що саме критерій $€$ основою для оцінки рівнів сформованості правової культури.

Ключові слова: критерії, показники, рівні сформованості правової культури майбутніх інженерів-педагогів, правова культура.

Соколова С. В. Критерии, показатели и уровни сформированности правовой культуры будущих инженеров-педагогов.

В статье рассматриваются мотивационно-ценностный, когнитивно-информационный, деятельностно-поведенческий, нравственно-личностный и оценочно-рефлексивный критерии, показатели и уровни сформированности правовой культуры будущих инженеров-педагогов. 